$\Phi$ ормирование воспаления и зуда у больных атопическим дерматитом и псориазом. Оценка экспрессии нейротрофинов и нейропептидов

\author{
В.А. Смольянникова², А.А. Кубанова', В.В. Чикин ${ }^{1}$, А.Э. Карамова ${ }^{1}$
}

1 ФГБУ «Государственный научный центр дерматовенерологии и косметологии» Минздрава России 107076, Москва, ул. Короленко, д. 3, стр. 6

${ }^{2}$ ГБОУ ВПО «Первый Московский государственный медицинский университет им. И.М. Сеченова» Минздрава России

119991, Москва, ул. Трубецкая, д. 8, стр. 2

Цель. Изучить экспрессию нейротрофина фрактора роста нервов, эпидермального фрактора роста амфирегулина, фактора редукции нервов семафорина-3А и маркера нервных волокон белка PGP9.5 в коже больных атопическим дерматитом и обыкновенным псориазом.

Материал и методы. Обследованы 30 больных атопическим дерматитом и 30 больных вульгарным псориазом.

Степень тяжести заболевания оценивали с помощью индексов SCORAD и PASI. Степень выраженности зуда оценивали с помощью визуальной аналоговой шкалы. Экспрессия амсирегулина, семафорина-3А, фактора роста нервов и маркера нервных волокон белка PGP9.5 в коже больных была определена методом непрямой иммунофлюоресценции. Оценку количественных параметров их экспрессии проводили с использованием базового комплекта программы Olympus Fluoview Ver. 1.7b.

Результаты. У обследованных больных атопическим дерматитом и псориазом обнаружено усиление выраженности иннервации эпидермиса, что свидетельствует об увеличении продукции в коже провоспалительных нейропептидов и снижении порога чувствительности к зуду. У больных атопическим дерматитом выявлена положительная корреляционная связь между степенью выраженности зуда и экспрессией в коже нейротросина фрактора роста нервов. У больных с тяжелой срормой псориаза обнаружено повышение экспрессии в коже эпидермального фрактора роста амфрирегулина.

Заключение. Полученные данные свидетельствуют о патогенетическом значении нейротрофина фрактора роста нервов в развитии зуда у больных атопическим дерматитом и амфирегулина при обыкновенном псориазе.

Ключевые слова: атопический дерматит, псориаз, фактор роста нервов, амфирегулин, семафорин-3А,

\title{
нервные волокна.
}




\title{
Inflammation and itching in patients suffering from atopic dermatitis and psoriasis. Assessment of the expression of neurotrophins and neuropeptides
}

\author{
V.A. Smolyannikova², A.A. Kubanova ${ }^{1}$, V.V. Chikin ${ }^{1}$, A.E. Karamova ${ }^{1}$
}

${ }^{1}$ State Research Center of Dermatovenereology and Cosmetology, Ministry of Healthcare of the Russian Federation Korolenko str., 3, bldg 6, Moscow, 107076, Russia

${ }^{2}$ I.M. Sechenov First Moscow State Medical University

Trubetskaya str., 8, bldg 2, Moscow, 119991, Russia

\begin{abstract}
Goal. To assess the expression of neurotrophin, a nerve growth factor, amphiregulin, an epidermal growth factor, semaphorin 3A, a nerve repulsion factor, and PGP9.5 protein, a nerve fiber marker, in the skin of patients suffering from atopic dermatitis and psoriasis.

Materials and methods. The study involved 30 patients suffering from atopic dermatitis and 30 patients suffering from psoriasis vulgaris. The disease severity was assessed by SCORAD and PASI. The extent of itching was assessed by the visual analogue scale. The expression of amphiregulin, semaphorin 3A (a nerve growth factor) and PGP9.5 protein (a nerve fiber marker) in the skin of patients was assessed by the indirect immunofluorescence method. Quantitative parameters of their expression were assessed by using the basic pack of the Olympus Fluoview software, Ver. 1.7b.

Results. Increased epidermal innervation was revealed in the patients suffering from atopic dermatitis and psoriasis, which demonstrates an increased skin production of anti-inflammatory neuropeptides and reduced itching sensitivity threshold. A positive correlation between the itching extent and skin expression of neurotrophin (a nerve growth factor) was revealed in the patients with atopic dermatitis. In patients with severe psoriasis, an increased skin expression of amphiregulin, an epidermal growth factor, was discovered.

Conclusion. These data demonstrate a pathogenic value of neurotrophin, a nerve growth factor, for the development of itching in patients with atopic dermatitis and amphiregulin in case of psoriasis vulgaris.
\end{abstract}

Key words: atopic dermatitis, psoriasis, nerve growth factor, amphiregulin, semaphorin $3 \mathrm{~A}$, nerve fibers.

Corresponding author: chikin@cnikvi.ru. Vestnik Dermatologii i Venerologii 2014; 6: 77_85. 
Атопический дерматит и псориаз входят в число наиболее распространенных хронических заболеваний кожи. Их развитие связано с нарушениями Т-клеточного иммунитета [1]. В патогенезе псориаза преобладают Th1-клеточные реакции с активацией Th1-лимфоцитов и продукцией провоспалительных цитокинов фрактора некроза опухоли- $\alpha$, интерферона- $\gamma$, интерлейкина-(ИЛ)-12, -17, -22 и -23, что приводит к ускорению пролифрерации кератиноцитов [2, 3]. Атопический дерматит характеризуется Th2-клеточными реакциями, сопровождающимися повышением продукции ИЛ-4, -5 и -13 [4, 5].

Современные методы терапии больных атопическим дерматитом и псориазом нацелены на подавление воспалительной реакции в коже, ассоциированной с характерными для каждого из этих заболеваний нарушениями Т-клеточного иммунитета и продукции цитокинов. Однако у части пациентов терапия не всегда оказывается эфффективной, что может быть связано с участием в патогенезе этих заболеваний не только цитокинов, но и других биологически активных веществ. Считается, что вместе с цитокинами в развитии воспалительной реакции принимают участие нейропептиды и нейротрофины [6-9].

Нейротрофины и нейропептиды, оказывая провоспалительное действие, могут усиливать интенсивность воспалительной реакции. Поскольку важным источником нейропептидов в коже являются окончания нервных волокон, то в патогенезе хронических воспалительных дерматозов предполагается участие нервных волокон кожи. Поэтому интенсивность воспалительной реакции у больных хроническими воспалительными дерматозами может зависеть от степени выраженности иннервации кожи. Значение периферической нервной системы в патогенезе заболеваний кожи заключается также в том, что чувствительные нервные С-волокна являются пруритоцептивными и воздействие на них приводит к развитию зуда. Причиной повышения выраженности иннервации кожи является дисбаланс между фракторами, стимулирующими рост нервов, - нейротрофином - фактором роста нервов, эпидермальным фактором роста амфирегулином и фракторами редукции нервов, к которым относится семафорин-ЗА, продуцируемый кератиноцитами [10].

В качестве показателя степени выраженности иннервации кожи может рассматриваться цитоплазматический белок нейронов PGP9.5, который представляет собой фермент убиквитин-С-терминальную гидролазу-1, специфический для нервной системы, в связи с чем он рассматривается как маркер нервной ткани [11-15]. Белок PGP9.5, действуя как убиквитин-С-терминальная гидролаза-1, участвует в регуляции деятельности системы убиквитин - протеасома, которая играет ключевую роль в контроле клеточного цикла, передаче сигналов внутри клеток, регуляции транскрипции, восстановления ДНК, реакций на стресс, программируемой клеточной гибели и презентации антигена $[16,17]$. Белок PGP9.5 усиливает действие циклин-зависимых киназ - основных фрерментов, регулирующих процессы клеточного цикла и пролиферации клеток, за счет чего он повышает пролиферацию клеток [18].

В связи с тем, что нервные волокна кожи, являясь источником провоспалительных нейропептидов, могут участвовать в патогенезе хронических воспалительных дерматозов, целью работы явилось определение экспрессии маркера нервных волокон белка PGP9.5 и веществ, влияющих на выраженность иннервации кожи, - фрактора роста нервов, амфрирегулина, семафорина-ЗА в коже больных атопическим дерматитом и обыкновенным псориазом.

\section{Материал и методы}

Проведено клиническое обследование 30 больных атопическим дерматитом (14 женщин и 16 мужчин в возрасте от 18 до 43 лет) и 30 больных обыкновенным псориазом (9 женщин и 21 мужчины в возрасте от 21 года до 68 лет). Степень тяжести течения заболевания у больных атопическим дерматитом определялась по индексу SCORAD. При индексе SCORAD менее 15 степень тяжести атопического дерматита расценивалась как легкая, при 15-40 - как средняя, выше 40 - как тяжелая.

Для оценки степени тяжести течения заболевания у больных обыкновенным псориазом использовали индекс PASI. Степень тяжести обыкновенного псориаза расценивали как легкую при PASI менее 10, среднюю - при индексе PASI 10-20 и как тяжелую при индексе PASI более 20.

C помощью визуальной аналоговой шкалы у больных атопическим дерматитом и обыкновенным псориазом определяли степень выраженности зуда, которую оценивали от 0 до 10 баллов. Отсутствию зуда соответствовало 0 баллов. Зуд расценивали как слабый, если степень его выраженности, согласно визуальной аналоговой шкале, составляла от 1 до 3 баллов, как умеренный - от 4 до 7 баллов, и как выраженный от 8 до 10 баллов.

В зависимости от степени тяжести болезни больные атопическим дерматитом и псориазом были разделены на группы со среднетяжелым и тяжелым заболеванием. Каждую группу составили по 15 человек.

Диагноз атопического дерматита и обыкновенного псориаза был подтвержден патоморфологически.

Экспрессию фактора роста нервов, амфирегулина, семафорина-3А и белка PGP9.5 в коже больных атопическим дерматитом и псориазом определяли методом непрямой иммунофлюоресценции на криостатных срезах согласно разработанному протоколу [19]. Оценка количественных параметров экспрессии белка PGP9.5, фрактора роста нервов, 
амфрирегулина и семафорина-3А проводилась с использованием базового комплекта программы Olympus Fluoview Ver. 1.7b.

Поскольку белок продукта гена PGP9.5 является маркером нервных волокон, его экспрессия позволила определить количество и среднюю длину нервных волокон, среднюю и суммарную интенсивность свечения нервных волокон, обнаруженных в препаратах кожи больных атопическим дерматитом и псориазом. Средняя интенсивность свечения позволяла оценить уровень активности нейронов. Для оценки количественных показателей экспрессии белка PGP9.5 сначала определяли локализацию PGP9.5-позитивных нервных волокон в поле зрения (в эпидермисе, в дерме, в зоне дермо-эпидермальной границы), затем измеряли показатель интенсивности свечения для каждого волокна по заданному каналу (в условных единицах), суммировали показатель интенсивности свечения для каждого поля зрения. В пределах одного биоптата выделяли по три поля зрения, для каждого из которых рассчитывался средний показатель экспрессии PGP9.5.

При измерении количественных показателей экспрессии фактора роста нервов, амфирегулина и семафорина-ЗА в поле зрения произвольным образом выделяли три одинаковые по площади зоны квадратной формы, в которых определялся средний показатель интенсивности свечения по заданному каналу (в условных единицах).

Контрольную группу составили 10 здоровых лиц, от которых были получены биоптаты кожи.

Статистическую обработку полученных данных проводили с помощью программы Statistica10, используя критерий Крускала - Уоллиса. Различия считали достоверными при уровне статистической значимости $p<0,05$. С помощью рангового коэфффициента корреляции Спирмена выявляли корреляционные связи между клиническими показателями и уровнем экспрессии в коже фрактора роста нервов, амфирегулина, семафорина-ЗА и маркера нервных волокон белка PGP9.5.

\section{Результаты}

При клиническом обследовании 30 больных атопическим дерматитом все больные предъявляли жалобы на зуд, индекс SCORAD составлял от 29,9 до 82,7 (в среднем $51,7 \pm 2,05)$. Выраженность зуда у больных атопическим дерматитом составляла от 2 до 10 баллов, в среднем 7,03 \pm 0,4 балла.

У 15 больных атопическим дерматитом индекс SCORAD колебался от 29,9 до 39,8, что соответствовало средней степени тяжести заболевания. Длительность заболевания варьировала от 2 до 40 лет, в среднем 14,22 $\pm 2,28$ года, число обострений заболевания - от 2 до 4 в год, в среднем $3,17 \pm 0,17$ в год. Степень выраженности зуда у 6,67\% больных ато- пическим дерматитом средней тяжести была слабой, у $86,67 \%$ - умеренной, у 6,67\% - выраженной.

У 15 больных атопическим дерматитом с индексом SCORAD от 46,5 до 82,7 заболевание расценивалось как тяжелое. Длительность заболевания у них составляла от 2 до 35 лет, в среднем - 15,09 2 2,15 года. У больных с тяжелым течением атопического дерматита число обострений заболевания составляло от 3 до 6 в год, в среднем - 4,82 $\pm 0,18$ в год, что было статистически значимо больше по сравнению с частотой обострений заболевания у больных атопическим дерматитом средней тяжести $(p<0,05)$. Среди 15 больных с тяжелой формой атопического дерматита слабый зуд был выявлен у 6,67\% пациентов, умеренный - у 6,67\%, выраженный - у 86,67\%.

У 30 больных обыкновенным псориазом индекс PASI составлял от 10,2 до 57. Степень выраженности зуда у больных псориазом составляла от 0 до 10, в среднем 6,00 $\pm 0,48$.

У 15 больных обыкновенным псориазом, у которых индекс PASI составлял от 10,2 до 19,7, был диагностирован псориаз средней степени тяжести. Длительность заболевания составляла от 4 лет до 31 года, в среднем - 12,17 $\pm 1,52$ года. Зуда не отмечали $6,66 \%$ больных псориазом средней тяжести, слабый зуд отмечался у 6,67\% пациентов, умеренный - у $80 \%$, выраженный - у 6,67\%.

У 15 больных обыкновенным псориазом индекс PASI составлял от 20,1 до 57, что соответствовало псориазу тяжелого течения. Длительность заболевания колебалась от 3 до 44 лет, в среднем - 20,86 $\pm 2,88$ года. В этой группе все пациенты отмечали зуд: слабый у $20 \%$; умеренный - у 20\%, выраженный - у $40 \%$.

Определяли уровень экспрессии маркера нервных волокон белка PGP9.5, амфирегулина, семафорина3А, фрактора роста нервов в коже больных атопическим дерматитом и обыкновенным псориазом. Статистически значимых различий в интенсивности свечения эпидермального фактора роста амфирегулина, семафорина-ЗА и фрактора роста нервов между группами больных атопическим дерматитом тяжелой и средней степени тяжести и здоровыми лицами контрольной группы выявлено не было (табл. 1). Вместе с тем зона экспрессии семафрорина-ЗА у больных атопическим дерматитом выявлялась преимущественно в базальном и супрабазальном слоях эпидермиса (рис. 1a), тогда как в контрольной группе его экспрессия была хорошо выражена во всех слоях эпидермиca, в зоне дермо-эпидермальной границы, в сосочковом слое дермы.

Выявлена положительная корреляционная связь между степенью выраженности зуда у больных атопическим дерматитом и интенсивностью свечения фактора роста нервов $(p=0,362 ; p<0,05)$.

Аналогичные результаты были получены у больных обыкновенным псориазом. Экспрессия семафорина-ЗА 
Таблица 1 Интенсивность свечения фракторов роста и редукции нервов в препаратах кожи больных атопическим дерматитом и псориазом, в усл. ед.; $M \pm m$

\begin{tabular}{lccc}
\hline Группа & Амсрирегулин & Семафорин-3А & Фактор роста нервов \\
\hline Больные атопическим дерматитом средней тяжести $(n=15)$ & $107,94 \pm 12,49$ & $161,02 \pm 25,49$ & $403,79 \pm 26,68$ \\
\hline Больные тяжелым атопическим дерматитом $(n=15)$ & $117,26 \pm 20,19$ & $163,14 \pm 13,91$ & $568,04 \pm 62,95$ \\
\hline Больные псориазом средней тяжести $(n=15)$ & $190,23 \pm 24,19$ & $228,10 \pm 14,09$ & $654,43 \pm 52,41$ \\
\hline Больные тяжелым псориазом $(n=15)$ & $201,05 \pm 24,62^{*}$ & $235,14 \pm 21,94$ & $736,85 \pm 77,99$ \\
\hline Контрольная группа $(n=10)$ & $109,9 \pm 24,71$ & $178,3 \pm 23,81$ & $485,5 \pm 75,1$ \\
\hline
\end{tabular}

Примечание. Здесь и в табл. 2: * — статистически значимое отличие от контрольной группы при $p<0,05$.

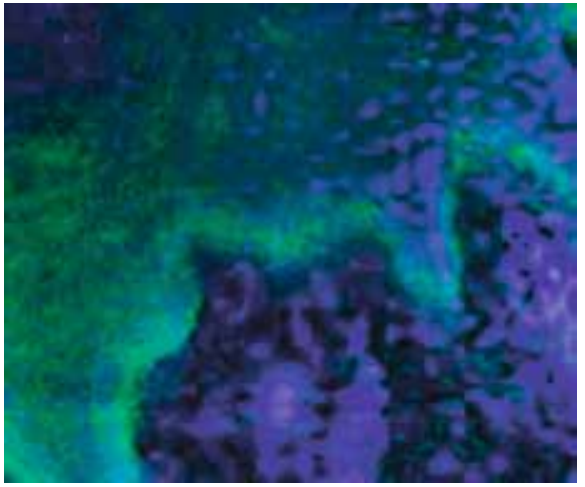

a

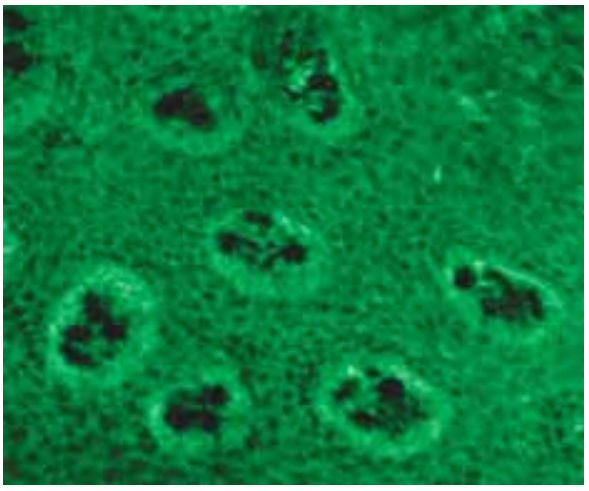

6

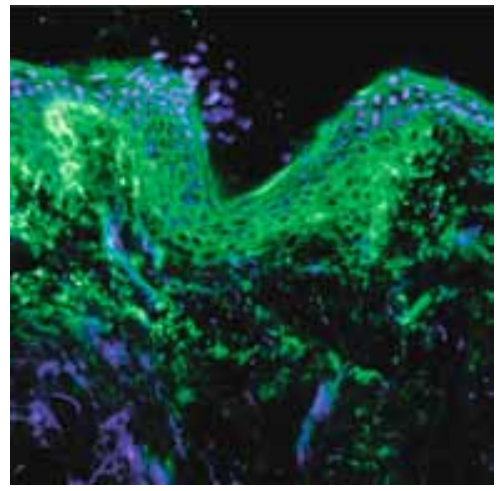

$B$

Экспрессия семафорина-3А в коже. ×100. а - при атопическом дерматите экспрессия снижена, наблюдается преимущественно в базальном и супрабазальных слоях эпидермиса; б - при псориазе экспрессия снижена, наблюдается преимущественно в базальном и супрабазальных слоях эпидермиса; в - у здорового человека экспрессия хорошо выражена во всех слоях эпидермиса, в зоне дермо-эпидермальной границы, в сосочковом слое дермы

у больных псориазом выявлялась в базальном и супрабазальном слоях эпидермиса (рис. 1б), тогда как в группе контроля его экспрессия наблюдалась во всех слоях эпидермиса, в зоне дермо-эпидермальной границы, в сосочковом слое дермы (рис. 1в). В группе больных с тяжелой формой псориаза интенсивность свечения амфирегулина (201,05 $\pm 24,62$ усл. ед.) была статистически значимо выше, чем в контрольной группе $(109,9 \pm 24,71$ усл. ед.; $p<0,05)$.

Корреляционных связей между степенью выраженности зуда и интенсивностью свечения амфирегулина, семафорина-ЗА и фрактора роста нервов в препаратах кожи больных псориазом выявлено не было.

В препаратах кожи больных атопическим дерматитом и обыкновенным псориазом была определена экспрессия маркера нервных волокон белка PGP9.5, которая позволила установить локализацию, количество и интенсивность свечения нервных волокон (рис. 2). В группах больных атопическим дерматитом было обнаружено прорастание нервных волокон в эпидермис, что не наблюдалось в контрольной группе.

Выявлено, что количество нервных волокон в эпидермисе больных тяжелым атопическим дерматитом составляет 7,73 $\pm 1,15$, что статистически значимо больше, чем в контрольной группе, $-1,00 \pm 0,55$ $(p<0,05)$ (табл. 2). Количество нервных волокон в эпидермисе больных псориазом средней $(7,86 \pm 1,46)$ и тяжелой степени тяжести $(10,67 \pm 1,61)$ также было статистически значимо больше, чем в контрольной группе $(1,00 \pm 0,55 ; p<0,05)$.

Выявлена положительная корреляционная связь между степенью тяжести атопического дерматита и количеством нервов в эпидермисе $(p=0,380 ; p<0,05)$ и дерме $(p=0,411 ; p<0,05)$ больных, а также между 


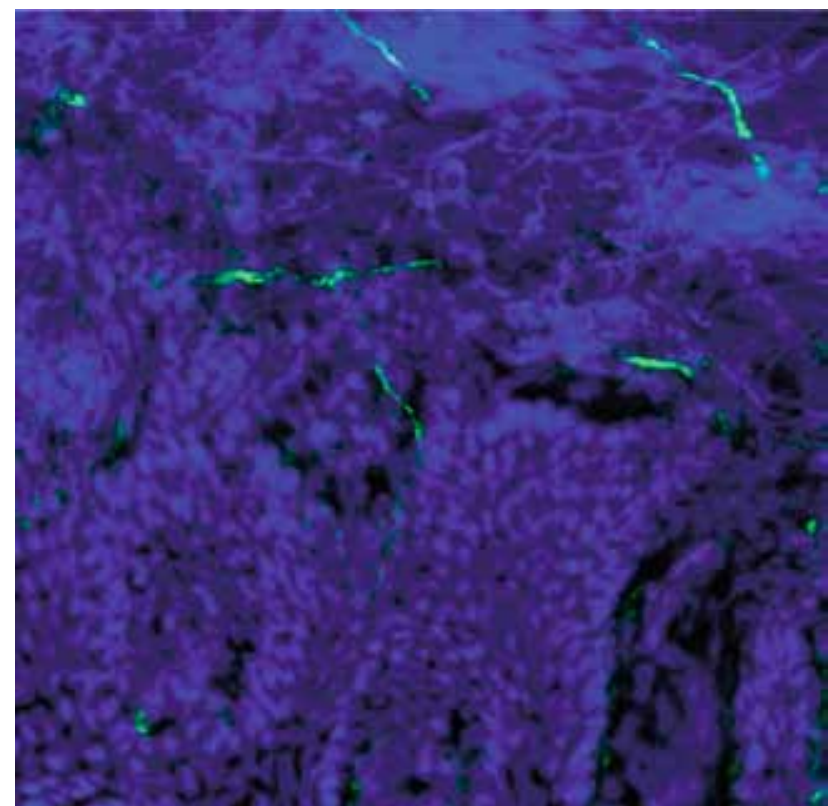

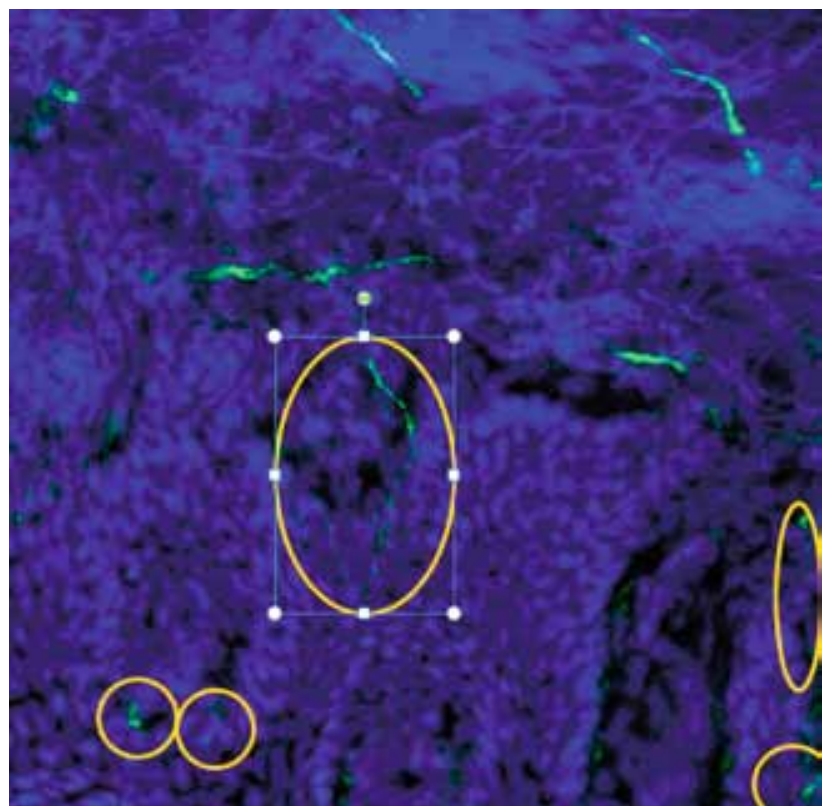

$\sigma$

Рис. 2. Определение экспрессии белка PGP9.5 в препаратах кожи больных псориазом (а). Определение локализации, числа и интенсивности свечения PGP9.5 позитивных нервных волокон (б). ×100

Таблица 2

Количество нервных волокон, обнаруженных в препаратах кожи больных атопическим дерматитом и псориазом

\begin{tabular}{lcccc}
\hline Группа & В эпидермисе & $\begin{array}{c}\text { На границе } \\
\text { эпидермиса и дермы }\end{array}$ & $\begin{array}{c}\text { В дерме } \\
\text { В препарате } \\
\text { суммарно }\end{array}$ \\
\hline Больные атопическим дерматитом средней тяжести $(n=15)$ & $5,13 \pm 0,72$ & $7,73 \pm 0,81$ & $17,00 \pm 1,65$ & $28,93 \pm 2,16$ \\
\hline Больные тяжелым атопическим дерматитом $(n=15)$ & $7,73 \pm 1,15^{*}$ & $9,27 \pm 1,65$ & $20,33 \pm 3,78$ & $37,33 \pm 5,06$ \\
\hline Больные псориазом средней тяжести $(n=15)$ & $7,86 \pm 1,46^{*}$ & $13,27 \pm 2,57$ & $12,60 \pm 1,12$ & $33,80 \pm 3,47$ \\
\hline Больные тяжелым псориазом $(n=15)$ & $10,67 \pm 1,61^{*}$ & $12,93 \pm 1,37$ & $13,53 \pm 1,19$ & $35,33 \pm 2,68$ \\
\hline Контрольная группа $(n=10)$ & $1,0 \pm 0,55$ & $6,78 \pm 2,17$ & $13,56 \pm 3,84$ & $21,33 \pm 5,90$ \\
\hline
\end{tabular}

степенью выраженности зуда у больных атопическим дерматитом и числом нервов в эпидермисе $(p=0,477$; $p<0,05)$, дерме $(p=0,364 ; p<0,05)$ и между степенью выраженности зуда и числом нервов в препарате кожи суммарно $(p=0,374 ; p<0,05)$.

У больных обыкновенным псориазом была выявлена положительная корреляционная связь между степенью тяжести заболевания и числом нервных волокон в эпидермисе $(p=0,423 ; p<0,05)$, а также между степенью интенсивности зуда и числом нервных волокон в эпидермисе $(p=0,405 ; p<0,05)$.

В группе больных тяжелым атопическим дерматитом средняя длина нервных волокон в эпидер- мисе составила 21,30 $\pm 2,86$ нм и была статистически значимо больше по сравнению с контрольной группой $-9,07 \pm 1,28$ нм $(p<0,05)$, на границе эпидермиса и дермы средняя длина нервных волокон - 36,95 $\pm 5,19$ нм также была больше, чем в контрольной группе, $-20,85 \pm 4,69$ нм $(p<0,05)$ (табл. 3). Кроме того, у больных с тяжелым течением атопического дерматита длина нервных волокон в дерме $(33,23 \pm 3,18$ нм) была статистически значимо больше, чем в контрольной группе $(21,77 \pm 2,31$ нм; $p<0,05)$, а также в препарате кожи суммарно $(32,41 \pm 1,31$ нм) в сравнении с группой контроля $(23,31 \pm 1,63 \mathrm{HM} ; p<0,05)$. 
Таблица 3

Средняя длина (в нм) нервных волокон, обнаруженных в препаратах кожи больных атопическим дерматитом и псориазом

\begin{tabular}{lcccc}
\hline Группа & В эпидермисе & $\begin{array}{c}\text { На границе } \\
\text { эпидермиса и дермы }\end{array}$ & $\begin{array}{c}\text { В дерме } \\
\text { В препарате } \\
\text { суммарно }\end{array}$ \\
\hline Больные атопическим дерматитом средней тяжести $(n=15)$ & $17,21 \pm 1,28$ & $20,39 \pm 1,69$ & $19,06 \pm 1,54$ & $18,64 \pm 1,31$ \\
\hline Больные тяжелым атопическим дерматитом $(n=15)$ & $21,30 \pm 2,86^{*}$ & $36,95 \pm 5,19^{*, \dagger}$ & $33,23 \pm 3,18^{*, \dagger}$ & $32,41 \pm 2,90^{*,+}$ \\
\hline Больные псориазом средней тяжести $(n=15)$ & $27,84 \pm 3,42^{*}$ & $29,24 \pm 3,22$ & $27,50 \pm 3,53$ & $29,20 \pm 2,92$ \\
\hline Больные тяжелым псориазом $(n=15)$ & $29,69 \pm 4,75^{*}$ & $32,29 \pm 4,71$ & $28,46 \pm 3,38$ & $31,70 \pm 4,21$ \\
\hline Контрольная группа $(n=10)$ & $9,07 \pm 4,53$ & $20,85 \pm 4,69$ & $21,77 \pm 2,31$ & $23,31 \pm 1,63$ \\
\hline
\end{tabular}

Примечание. * - статистически значимое отличие от контрольной группы $(p<0,05){ }^{\dagger}$ — статистически значимое отличие от группы больных атопическим дерматитом средней тяжести $(p<0,05)$.

У больных с тяжелой формой атопического дерматита средняя длина нервных волокон была статистически значимо больше на границе эпидермиса и дермы (36,95 \pm 5,19 нм) по сравнению с больными атопическим дерматитом средней тяжести $(20,39 \pm 1,69$ нм; $p<0,05)$, в дерме $(33,23 \pm 3,18$ нм $)-$ по сравнению с больными атопическим дерматитом средней тяжести $(19,06 \pm 1,54$ нм; $p<0,05)$ и в препарате кожи суммарно $(32,41 \pm 1,31$ нм) - по сравнению с больными атопическим дерматитом средней тяжести $(18,64 \pm 1,31$ нм; $p<0,05)$. В группе больных с тяжелым течением атопического дерматита не выявлено статистически значимых отличий средней длины нервных волокон в эпидермисе от показателя в группе больных атопическим дерматитом средней тяжести.

Выявлена положительная корреляционная связь между степенью тяжести атопического дерматита и средней длиной нервных волокон в эпидермисе $(p=0,387 ; p<0,05)$, на границе эпидермиса и дермы $(p=0,443 ; p<0,05)$, в дерме $(p=0,636 ; p<0,05)$, между степенью тяжести атопического дерматита и средней длиной нервных волокон в препарате кожи суммарно $(p=0,627 ; p<0,05)$. Кроме того, выявлена положительная корреляционная связь между степенью выраженности зуда у больных атопическим дерматитом и средней длиной нервных волокон в эпидермисе $(p=0,442 ; p<0,05)$, в дерме $(p=0,605 ; p<0,05)$ и в препарате кожи суммарно $(p=0,420 ; p<0,05)$. Корреляционных связей между степенью выраженности зуда у больных атопическим дерматитом и средней длиной нервных волокон на границе эпидермиса и дермы не установлено.

У больных псориазом средней степени тяжести средняя длина нервных волокон в эпидермисе составила 27,84 \pm 3,42 нм, в группе больных с тяжелой формой псориаза $(29,69 \pm$ 4,75 нм) статистически значимых различий между группами не обнаружено.

У больных псориазом выявлена положительная корреляционная связь между степенью тяжести за- болевания и средней длиной нервных волокон в эпидермисе $(p=0,362 ; p<0,05)$. Корреляционных связей между степенью выраженности зуда у больных псориазом и средней длиной нервных волокон в эпидермисе, на границе эпидермиса и дермы, в дерме и в препарате кожи суммарно не обнаружено.

Средняя интенсивность свечения нервных волокон в эпидермисе больных атопическим дерматитом средней тяжести составила 1029,89 \pm 32,41 усл. ед., тяжелым - 1068,02 \pm 125,51 усл. ед. и была статистически значимо выше, чем в контрольной группе, $-548,13 \pm 220,09$ усл. ед. $(p<0,05)$. Сравнение средней интенсивности свечения нервных волокон в препаратах кожи больных с тяжелой и средней степенью тяжести атопического дерматита не выявило статистически значимых различий между этими группами.

Выявлена положительная корреляционная связь между степенью тяжести заболевания у больных атопическим дерматитом и средней интенсивностью свечения нервных волокон в дерме $(p=0,424 ; p<0,05)$, а также суммарной интенсивностью свечения нервных волокон в дерме $(p=0,446 ; p<0,05)$ и в целом в препаратах кожи $(p=0,461 ; p<0,05)$. Кроме того, у больных атопическим дерматитом выявлена положительная корреляционная связь между степенью выраженности зуда и суммарной интенсивностью свечения нервных волокон в дерме $(p=0,393 ; p<0,05)$.

У больных псориазом средней степени тяжести средняя интенсивность свечения нервных волокон в эпидермисе составила 1035,46 $\pm 45,13$ усл. ед., тяжелой формы - 1125,76 \pm 41,86 усл. ед., что статистически значимо выше, чем в контрольной группе, $548,13 \pm 220,09$ усл. ед. $(p<0,05)$. Проведенное сравнение средней и суммарной интенсивности свечения нервных волокон в препаратах кожи больных псориазом тяжелой и средней степени тяжести не выявило статистически значимых различий. Установлена положительная корреляционная связь между степенью 
тяжести псориаза и средней интенсивностью свечения нервных волокон в дерме $(p=0,420 ; p<0,05)$.

Сравнение суммарной интенсивности свечения нервных волокон в эпидермисе, на границе эпидермиса и дермы, в дерме и в препарате суммарно между группами больных с тяжелой формой псориаза и больных псориазом средней тяжести статистически значимых различий не выявило. Корреляционных связей между степенью тяжести псориаза, степенью интенсивности зуда и суммарной интенсивностью свечения нервных волокон в эпидермисе, на границе эпидермиса и дермы, в дерме и в препарате кожи суммарно не обнаружено.

\section{Обсуждение}

На основании проведенной количественной оценки экспрессии маркера нервных волокон (белка PGP9.5), эпидермального фрактора роста (амфирегулина), фактора редукции нервов (семафорина-3А), нейротрофина (фрактора роста нервов) в коже больных атопическим дерматитом и псориазом методом непрямой иммунофлюоресценции можно сделать следующие выводы.

Полученные результаты свидетельствуют о дисбалансе в коже больных атопическим дерматитом и обыкновенным псориазом факторов, влияющих на иннервацию кожи. Этот дисбаланс проявляется возрастанием влияния факторов, способствующих повышению иннервации кожи, о чем свидетельствует выявленная положительная корреляционная связь между степенью выраженности зуда у больных атопическим дерматитом и содержанием в их коже нейротрофина фактора роста нервов, увеличение содержания эпидермального фрактора роста амфирегулина в коже больных тяжелым псориазом.

Данные о преобладании эффректов веществ, способствующих разрастанию нервных волокон, у больных атопическим дерматитом и обыкновенным псориазом подтверждаются тем, что атопический дерматит и псориаз характеризуются увеличением числа, длины и интенсивности свечения нервных волокон в эпидермисе.

Длина нервных волокон в коже больных атопическим дерматитом увеличивается по мере увеличения тяжести заболевания: тяжелый атопический дерма- тит сопровождается увеличением длины нервных волокон в дерме и на дермо-эпидермальной границе, а также повышением средней интенсивности их свечения. Имеется прямая корреляционная связь между тяжестью атопического дерматита, оцененной с учетом индекса SCORAD, и количеством, длиной и средней интенсивностью свечения нервных волокон в эпидермисе. Выявлена положительная корреляционная связь между степенью выраженности зуда и количеством, длиной и средней интенсивностью свечения нервных волокон. В целом у больных тяжелым атопическим дерматитом отмечается увеличение количества нервных волокон как в эпидермисе, так и в дерме.

У больных обыкновенным псориазом выявлена положительная корреляционная зависимость между тяжестью заболевания, оцененной с учетом индекса PASI, и количеством и длиной нервных волокон в эпидермисе и их суммарной интенсивностью свечения, а также суммарной интенсивностью свечения нервных волокон в дерме. При тяжелом течении псориаза выявлено повышение интенсивности свечения эпидермального фрактора роста амфирегулина. Достоверных различий между группами больных с тяжелой и средней степенью тяжести псориаза по количеству, длине и интенсивности свечения нервных волокон, а также по продукции фактора редукции нервов семафоринаЗА и нейротрофрина фрактора роста нервов не обнаружено в отличие от группы больных с атопическим дерматитом. Выявлена прямая корреляционная зависимость между степенью выраженности зуда и числом нервных волокон в эпидермисе.

Таким образом, полученные данные подтверждают, что важную роль в патогенезе хронических воспалительных дерматозов - атопического дерматита и псориаза - наряду с иммунными механизмами играют нейропептиды и нейротрофины. Дальнейшее изучение этого направления приведет к возможности разработки патогенетической терапии атопического дерматита и псориаза, направленной на блокирование эфффектов нейромедиаторов, способствующих развитию воспаления и зуда, либо на стимуляцию эффектов веществ, препятствующих патологическому разрастанию чувствительных нервных окончаний, воспринимающих зуд. І

\section{Литература}

1. Guttman-Yassky E., Nograles K.E., Krueger J.G. Contrasting pathogenesis of atopic dermatitis and psoriasis - Part I. Clinical and pathologic concepts. J Allergy Clin Immunol 2011; 127: $1110-1118$.

2. Lowes M.A., Suarez-Farinas M., Krueger J.G. Immunology of psoriasis. Annu. Rev. Immunol. 2014; 32: 227-255
3. Ryan C., Korman N.J., Gelfand J.M. Research gaps in psoriasis: opportunities for future studies. J Am Acad Dermatol 2014: 70 (1): 146_-167.

4. Boguniewicz M., Leung D.Y. Atopic dermatitis: a disease of altered skin barrier and immune dysregulation. Immunol Rev. 2011; 242 (1): 233-246.
5. Lewin J., Friedlander S.F., Del Rosso J.Q. Atopic dermatitis and the stratum corneum: part 3: the immune system in atopic dermatitis. J Clin Aesthet Dermatol. 2013; 6 (12): 37-44.

6. Vega J.A., Garcia-Suarez O., Hannestad J. et al. Neurotrophins and the immune system. J Anat 2003; 203: 1-19. 
7. Peters E.M., Ericson M.E., Hosoi J. et al. Neuropeptide control mechanisms in cutaneous biology: physiological and clinical significance. J Invest Dermatol 2006; 126: 1937-1947.

8. Franco R., Pacheco R., LLuis C. et al. The emergence of neurotransmitters as immune modulators. Trends Immunol 2007; 28 (9): 400—407.

9. Lotti T., D'Erme A.M., Hercogova J. The role of neuropeptides in the control of regional immunity. Clin Dermatol 2014; 32: 633—645.

10. Tominaga M., Takamori K. An update on peripheral mechanisms and treatments of itch. Biol Pharm Bull 2013; 36 (8): 1241-1247.

11. Jackson P., Thomson V.M., Thompson R.J. A comparison of the evolutionary distribution of the two neuroendocrine markers, neuronespecific enolase and protein gene product 9.5 . J Neurochem 1985; 45: 185-190.
12. Day I.N., Thompson R.J. Molecular cloning of CDNA coding for human PGP 9.5 protein. A novel cytoplasmic marker for neurones and neuroendocrine cells. FEBS Lett, 1987; 210: 157-160.

13. Wilkinson K.D., Lee K.M., Deshpande S. et al. The neuron-specific protein PGP 9.5 is a ubiquitin carboxyl-terminal hydrolase. Science 1989; 246: 670 -673.

14. Day I.N. Enolases and PGP9.5 as tissue-specific markers. Biochem Soc Trans 1992; 20, 637-642.

15. Day I.N., Thompson R.J. UCHL1 (PGP 9.5): Neuronal biomarker and ubiquitin system protein. Prog Neurobiol 2010; 90: 327-362.
16. Hershko A., Ciechanover A. The ubiquitin system. Annu Rev Biochem 1998; 67: 425—479.

17. Wilkinson K.D. Roles of ubiquitinylation in proteolysis and cellular regulation. Ann Rev Nutr 1995; 15: 161-189.

18. Kabuta T., Mitsui T., Takahashi M. et al. Ubiquitin C-terminal hydrolase L1 (UCH-L1) acts as a novel potentiator of cyclin-dependent kinases to enhance cell proliferation independently of its hydrolase activity.

19. Катунина О.Р., Чикин В.В., Знаменская Л.Ф., Иноятова Л.А. Роль нейромедиаторов в развитии воспаления в коже больных атопическим дерматитом. Вестн дерматол венерол 2013, (5): 91-101.

об авторах:
А.А. Кубанова - д.м.Н., академик РАН, директор ФГБУ «ГНЦДК» Минздрава России, Москва
В.А. Смольянникова - д.м.н., профессор кафедры патологической анатомии ГБОУ ВПО «Первый МГМУ им. И.М. Сеченова» Минздрава России, Москва

В.В. Чикин - к.м.Н., старший научный сотрудник отдела дерматологии ФГБУ «ГНЦДК» Минздрава России, Москва

А.Э. Карамова — к.м.Н., ведущий научный сотрудник научной части ФГБУ «ГНЦДК» Минздрава России, Москва

\section{Конфликт интересов}

Авторы заявляют об отсутствии потенциального конфликта интересов, требующего раскрытия в данной статье 